\title{
Research of Flood Control Regulation Based on Distributed Model in Luhun Reservoir, China
}

\author{
Linying $\mathrm{Lv}^{1}$, Caihong $\mathrm{Hu}^{1}$, Xinjian Guan ${ }^{1} \&$ Zhimin $\mathrm{Shi}^{2}$ \\ ${ }^{1}$ College of Water Conservancy and Environmental Engineering, Zhengzhou University, China \\ ${ }^{2}$ Hydraulic Engineering Prospecting and Design Institute of North Henan, China \\ Correspondence: Caihong Hu, College of Water Conservancy and Environmental Engineering, Zhengzhou \\ University, China. E-mail: hucaihong@zzu.edu.cn
}

Received: September 23, 2014 Accepted: October 3, 2014 Online Published: October 23, 2014

doi:10.5539/esr.v4n1p21

URL: http://dx.doi.org/10.5539/esr.v4n1p21

\begin{abstract}
In charge of both the flood control of its area and the reduction of floods in downstream of Yellow River, Luhun reservoir is in a absolutely pivotal position. Thus, the research concerning about the flood control scheduling scheme and strategy in Luhun catchment is imperatively essential. Based on the flood data of Luhun reservoir in the year 1980-1998, the study establish a loose distributed hydrological model, which is able to reflect excess storage runoff and excess infiltration runoff simultaneously, to forecast the flood in the section. The other function of the model can effectively obtain spatial distribution of underlying surface from the researched catchment as well as combine weather data conveniently. Subsequently, combining with the DEM data, the catchment was divided into 13 sub-basins on the basis of characteristics of the watershed topography, land use, soil and vegetation distribution. After the information of the sub-streams is acquired, the spatial distribution of the runoff and the flood will be analyzed. Further, it draws a conclusion that the model used is suitable for Luhun catchment, and technical support for flood control can be provided in the section. Meanwhile, pointed flood control strategies are presented in Luhun reservoir.
\end{abstract}

Keywords: Luhun catchment, distributed hydrological model, runoff distribution, flood control strategies

\section{Introduction}

As one of the most frequently damaging natural disasters in China, flood catastrophe losses with annual average more than 200 billion RMB in recent years (Cheng \& chau, 2004). Yangtze River Basin and Huaihe River Basin suffered great flood in 1998 and 2003 separately. At the same time, the same situation happened within the year of 2007 in Jinnan and 2012 in Beijing. The fact of all those events demonstrated that appropriate control of reservoir is vitally important. The main point of flood control is to realize the maximum utilization of flood management and the minimum loss of flood catastrophe (Ceccato, Gianini \& Giupponi, 2011; Xia 2005).

Located in the midstream of the Yellow River, the Luhun Catchment is in charge of the flood control security of its area, as well as the reduction of flood peak and flood volume in downstream of the Yellow River along with Sanmenxia Reservoir, Xiaolangdi Reservoir and Guxian Reservoir. Give that both of the responsibilities are realized through cutting down the volume of floods in Yiluo River, studying the flood control scheduling scheme and strategy of Luhun reservoir becomes vitally important. On the basis of analysis about the main uncertainty factors that affect the flood control scheduling and the real situation of Luhun Catchment, $\mathrm{Liu}, \mathrm{Hu}$, Wang and $\mathrm{Wu}$ (2005) discussed the computing method of risk analysis. And they worked out the implementation procedure about the risk analysis of flood control scheduling in reservoir by using Monte-Carlo simulation technology. Zhao, P. Zhang and H. Zhang (2010) explored joint optimization system of the benefit from flood control and power station. Furthermore, they made an organic combine of the flood control optimal operation and the benefit optimal operation under security environment by using the existing water resources of the reservoir and its power. Moreover, according to the discrete differential dynamic program method, $\mathrm{Xu}, \mathrm{Hu}$ and $\mathrm{Wu}$ (2011) constructed a single reservoir and multi-objective optimization scheduling model of Luhun Catchment and got the optimal scheduling operation of Luhun Catchment. Even though there are many studies on flood and disaster control of Luhun Catchment, most of which are concerned about flood control strategies of Luhun Catchment from the aspects of resources and optimal target, nevertheless those studies lack of condition on flood characteristics and flood progress. Lucubrating formation progress of flood helps to provide more accurate targeted flood control 
strategy, while advanced model simulation technology is possible for reducing, or even avoiding the degradation caused by floods (Beven, 2004). Hydrological model is frequently used in flood forecasting and flood control regulation, which becomes a tendency. Beven and Kirbby (1979) excogitated TOPMODEL model that is a half-distributed hydrological model taking landform into account. Later on, there came IHDM model, SWAT model and Modified TOPNET model (Wood, 1996; Akhavana et al., 2010; Bandaragoda, Tarboton \&Woods, 2004). In virtue of soft ArcGIS to acquire the information of basins, some model becomes suitable for ungauged basin (Cuartas et al., 2012). Breckpot et al. (2013) used a linear model for the Demer, a river in Belgium, that is derived, which is used inside the optimization problem solved by the controller. While all these models mentioned above have good flexibility in humid region, but for semi-arid regions, the more complex, explicit soil-moisture-accounting models perform in a manner which is demonstrably superior to the simpler, implicit soil-moisture-accounting types (World Meteorological Organization, 1975, 1986).Unlike the models used, the newly-built hydrological model in the research is a loosely coupled distributed watershed hydrological model which reflects excess infiltration and excess storage simultaneously (Zhan \&Ye, 2006; Bao, 2007). The merit of the model is that it can takes the characteristics of runoff in semi-arid and semi-humid region and the inhomogeneity of precipitation into account as well as the uneven underlying surface. Hence, the model can put forward flood control strategies effectively in semi-arid and semi-humid region such as Luhun catchment not only from the chemical progress, but also from the flood formation and the flood spatial distribution. Further and even more important, the paper analyzed the features of rainstorm and the runoff distribution in 13 sub-streams divided by ARCGIS. On the one hand, it came to a conclusion that the model used is suitable for Luhun catchment, on the other hand, based on the calculation results of the model which was proved to be valid, technology suggestions and strategies about flood control scheduling work in Luhun Catchment are provided.

\section{Construction of Model and Data}

\subsection{Profile of Luhun Catchment}

\subsubsection{Geographical Position}

As a branch of Yi River in Yellow River, Luhun catchment has an area of $3492 \mathrm{~km}^{2}$. Located in Song county in Henan province, the reservoir of the catchment is a large comprehensive reservoir for the main purpose of flood-control, as well as irrigation, electricity generation etc. The design criterion of Luhun reservoir is that flood happens once per millennium and one time in ten thousand years for flood check. Yi River catchment lies $\mathrm{E}$

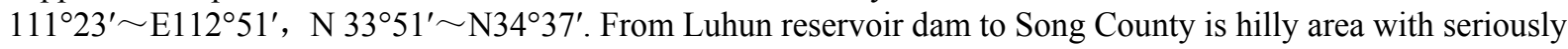
damaged natural vegetation, from Song County to Jiu County is semi-mountainous region and above Jiu County is rocky-mountain. With warm temperate continental monsoon climate, the Yi River has cold winter, less rain and $11 \%$ of the whole year's precipitation. In summer, it is hot, rainy and charges for $55.7 \%$ precipitation of the whole year. In a word, the characters of the precipitation in Yi River are huge inter-annual variation and uneven distribution of the year.

\subsubsection{Information Based on DEM}

Based on the DEM data of Luhun reservoir, Luhun catchment is divided into 13 parts by the Hydrology Model in GIS. The division and precipitation station of different parts of Luhun catchment are showed as figure 1. In this way, a series of basic parameters and digital hydrologic parameters of each sub-catchment can be obtained. It includes information like the characters of the river in the catchment and its sub-catchments, soil type, the ground truth, land utilize map and so on. 


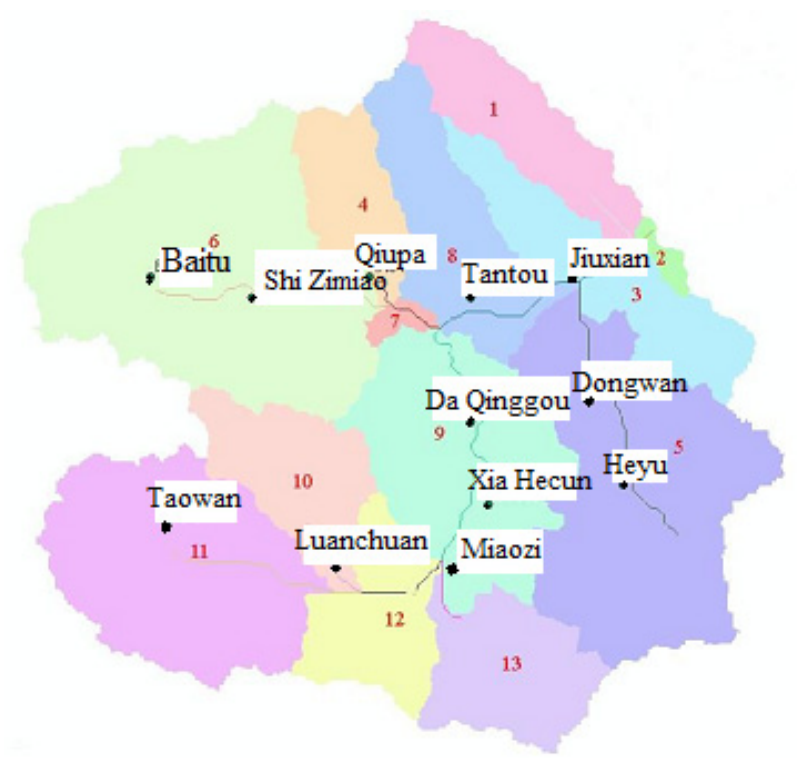

Figure 1. Division of sub-streams and precipitation station

After extracting the information of the area, there exist four kinds of soil in Luhun catchment. They are yellow brown soil, cinnamon soil, neutral rocky soil and red clay. A large proportion of the area in Luhun catchment is covered by cinnamon soil and yellow brown soil, the ratios of which are $46.17 \%$ and $41.44 \%$ respectively. In addition, the main land-use form of Luhun catchment includes deciduous forest, mixed forest, evergreen forest, orchards, grassland, summer pastures, the beach, medium density residential areas, low density residential areas, corn and soybeans fields. Different land-use form is with various water contents, the grassland is on the leading place, the shrubby land is on the move, and the arboreal land has the least water content.

\subsection{Constructions of Model}

In semi-arid and semi-humid region, the runoff mechanism is not simplex but complex, there may be often contain both saturation excess and infiltration excess. So it need a distributed hydrologic model that can take the two runoff mechanisms into account and can handle problems such as the inhomogeneity in time and space of rainfall (Chen, Ren, Xu \& Huang, 2010). The distributed hydrologic model built in the paper can reflects excess infiltration runoff and excess storage runoff simultaneously. In the infiltration excess runoff pattern, the infiltration rate that is less than infiltration intensity is immobile. Meanwhile, there only existing surface runoff because that underground runoff and soil runoff almost to be zero so that they can be ignored. While when the runoff pattern is saturated, the water in aeration zone is saturated, and the infiltrating water comes to be soil runoff RI and underground runoff $\mathrm{RG}(\mathrm{Li}, 2011)$.

The model is constituted in four phase as Figure 2 reveals. They are evapotranspiration, runoff generation in cell, flow concentration in cell, underground runoff and flow and runoff generation in drainage basin. The evapotranspiration component is calculated by a three soil layer model (Hu, Xiong, Guo \& Peng, 2005).In part "runoff generation calculation in cell", the digital drainage of the basin is extracted out on the basis of DEM data by soft ArcGIS, meanwhile, according to water division idea of Xinanjiang model (Zhao, 1980), the runoffs are divided into surface runoff, soil runoff and underground runoff. The flow concentration of Surface runoff is based on non-dimensional unit hydrograph, while soil runoff and underground runoff are calculated through linear reservoir method. After the flow in each sub basin is calculated, counting the flow concentration in watercourse by Muskingum method (Kumar, Baliarsingh \& Raju, 2010), then adding it together to present the flow capacity in the exit of the catchment. 


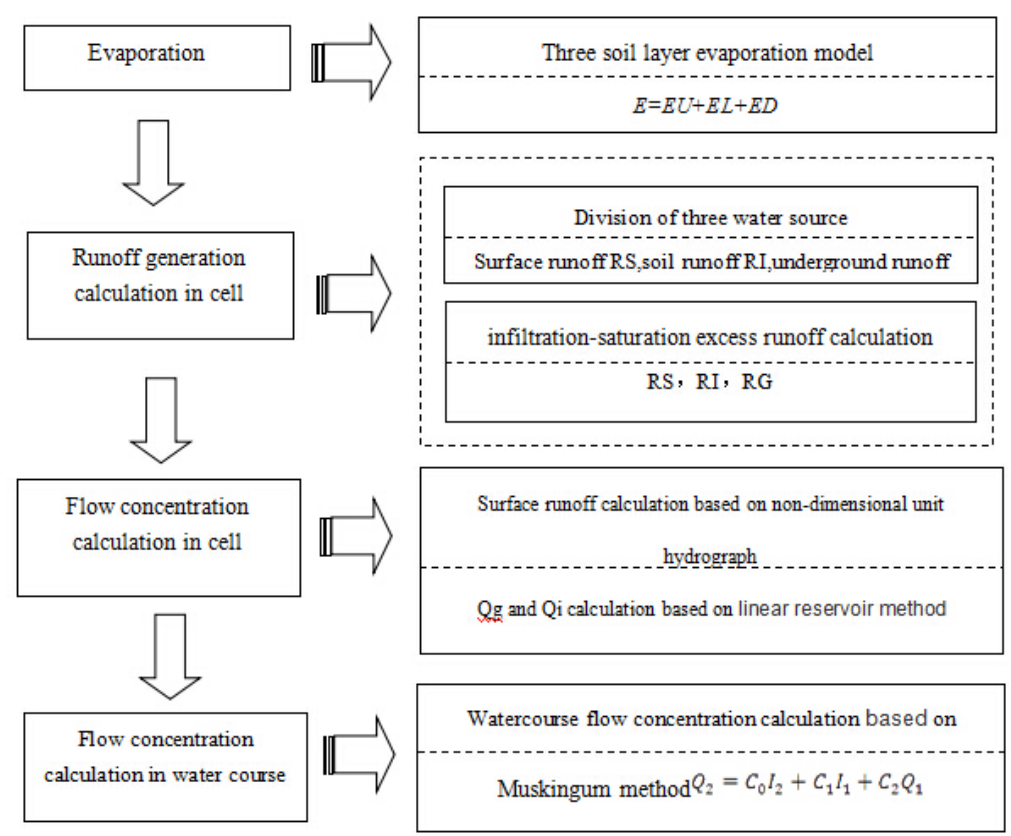

Figure 2. The constructions of the model

As study illustrates, excess storage runoff and excess infiltration runoff flood may exist a mere or exist simultaneously. Therefore, the two types of runoff model are all should be taken into account when calculating the runoff in semi-arid and semi-humid region. The runoff model of Luhun catchment, which is a semi-arid and semi-humid area, is excess storage and excess infiltration simultaneously. While in the sub-basins, the runoffs are divided into 6 forms according to different rainfall, moisture contents in soil, the relationship among different curves including the storage capacity curve in basin, the infiltration capacity distribution curve etc. In regard to the processes of runoffs, separately calculation is necessary through six different formulas denoted in reference (Hu and Wang, 2010).

\subsection{Evaluation Results of Model}

As the "Forecasting Norm for Hydrology Intelligence"(GB / T 22482--2008)indicates, accuracy assessment is based on all the information included in flood forecast scheme, while, accuracy test should quote information of the floods which are not compiled in flood forecast scheme. The contents of flood accuracy assessment include flood peak discharge, time of peak flow, flood volume, flood hygrograph etc. The main indicators which the assessment adopts are Nash-Sutcliffe, absolute error, relative error and the like.

In the process of flood forecast, $20 \%$ of the actual flood peak discharge is treated as allowable error of peak discharge. Nevertheless, the allowable error equals $5 \%$ of the actual flood peak discharge when it is less than 5\% of the actual flood peak discharge. The allowable error about the forecast of peak time, which is evaluated to be $3 \mathrm{~h}$ or a calculative period if the allowable error is less than $3 \mathrm{~h}$ or a calculative period, equals the $30 \%$ of the time distance which is from forecast time to time of reaching the actual measured peak. The simulated result of the model is up to the standard when the actual error is less than allowance error. In general, the results of flood forecast are divided into three degrees as $\mathrm{A}, \mathrm{B}, \mathrm{C}$ referencing qualified rate, which is as much as the times of up-standard forecast divides the total times of forecasts, and Nash benefit coefficient. As table 1 reveals, the forecast can be released officially in case the accuracy of flood forecast is A or B. When the accuracy of the forecast can achieve C-the third level, it can supply references for practical flood forecast. However, when lower than that, the data can be only used for referential estimate.

Table 1 . The grade of forecasting accuracy

\begin{tabular}{cccc}
\hline Grade of Accuracy & $\mathrm{A}$ & $\mathrm{B}$ & $\mathrm{C}$ \\
\hline Qualified rate $(\%)$ & $\mathrm{QR} \geq 85.0$ & $85.0 \geq \mathrm{QR} \geq 70.0$ & $70.0 \geq \mathrm{QR} \geq 60.0$ \\
Nash-Sutcliffe & $\mathrm{DC} \geq 0.90$ & $0.90 \geq \mathrm{DC} \geq 0.70$ & $0.70 \geq \mathrm{DC} \geq 0.5$ \\
\hline
\end{tabular}




\subsection{Data}

The basic data used in the research is extracted from 15-year flood seasons during June to October in the period of 1980 to 1998. The hydrologic data which is measured in Dongwan station contains two-hour precipitation, evaporation, flood and so on. Not all the floods in the period but only 12 floods, among which the first 8 floods are calibration period and the last 4 floods are validation period, are selected to make study. At the point, making accuracy assessments on the result that is achieved through distributed hydrological model. As long as the model accuracy is reasonable, the model can be used to analyze the runoff characteristics of the Luhun catchment. The summary information in detail about different floods is denoted in the following Table 2.

Table 2. The summary information in detail of floods

\begin{tabular}{|c|c|c|c|c|c|c|c|}
\hline Items & Flood NO. & $\mathrm{Y}$ & $\begin{array}{l}\text { Start time } \\
\text { M-D-H }\end{array}$ & $\begin{array}{l}\text { End time } \\
\text { M-D-H }\end{array}$ & $\begin{array}{c}\text { Flood } \\
\text { Peak }\left(\mathrm{m}^{3} / \mathrm{s}\right)\end{array}$ & $\begin{array}{c}\text { Flood } \\
\text { Volume }\left(10^{6} \mathrm{~m}^{3}\right)\end{array}$ & $\begin{array}{l}\text { Last } \\
\text { (h) }\end{array}$ \\
\hline & 80062904 & 1980 & $6-29-4$ & $7-9-16$ & 744 & 104.1 & 254 \\
\hline & 81071322 & 1981 & $7-13-22$ & $7-18-22$ & 482 & 44.3 & 122 \\
\hline & 83072706 & 1983 & $7-27-06$ & $8-9-20$ & 708 & 145.5 & 328 \\
\hline Calibratio--n & 83093000 & 1983 & $9-30-00$ & $10-30-6$ & 1290 & 380.0 & 728 \\
\hline \multirow[t]{5}{*}{ Period } & 84090116 & 1984 & $9-1-16$ & $10-15-20$ & 1210 & 616.9 & 1062 \\
\hline & 88080808 & 1988 & $8-8-8$ & $8-28-8$ & 602 & 214.6 & 482 \\
\hline & 90072012 & 1990 & $7-20-12$ & $7-24-18$ & 542 & 38.5 & 104 \\
\hline & 94070220 & 1994 & $7-2-20$ & $7-5-22$ & 1210 & 40.7 & 76 \\
\hline & 95081110 & 1995 & $8-11-10$ & $8-17-14$ & 848 & 81.2 & 150 \\
\hline Validation & 96080100 & 1996 & $8-1-0$ & $8-9-22$ & 1730 & 261.9 & 216 \\
\hline \multirow[t]{2}{*}{ Period } & 96091618 & 1996 & $9-16-18$ & $9-25-14$ & 809 & 121.7 & 214 \\
\hline & 98080304 & 1998 & $8-3-4$ & $8-21-6$ & 1320 & 229.0 & 436 \\
\hline
\end{tabular}

\section{Model Simulation Results and Control Strategies}

\subsection{The Analysis of Simulation Results}

Drawing support from computer technique and abiding by calculation principle and the evaluation criterion of the model, the simulation accuracy for the result is marked in Table 3. And the figure 3 presents the fitted situation of the simulative flood and the measured flood.

Table 3 . The accuracy of the result simulated by distributed hydrological model

\begin{tabular}{|c|c|c|c|c|c|c|c|c|c|}
\hline \multirow{2}{*}{ Items } & \multirow{2}{*}{$\begin{array}{l}\text { Flood } \\
\text { No. }\end{array}$} & \multirow{2}{*}{$\begin{array}{c}\text { Predicted } \\
\text { Flood } \\
\text { Peak }\left(\mathrm{m}^{3} / \mathrm{s}\right)\end{array}$} & \multirow{2}{*}{$\begin{array}{c}\text { Measured } \\
\text { Flood } \\
\text { Peak }\left(\mathrm{m}^{3} / \mathrm{s}\right)\end{array}$} & \multirow{2}{*}{ Nash } & \multicolumn{2}{|c|}{$\mathrm{R}^{2}$} & \multirow{2}{*}{$\begin{array}{c}\text { Per-e } \\
\text { Flood } \\
\text { Peak }(\%)\end{array}$} & \multirow{2}{*}{$\begin{array}{c}\text { Per-e } \\
\text { Flood } \\
\text { Volume } \\
(\%)\end{array}$} & \multirow{2}{*}{$\begin{array}{c}\text { A-Time of } \\
\text { Flood } \\
\text { peak }(\mathrm{h})\end{array}$} \\
\hline & & & & & No. & Grade & & & \\
\hline & 80062904 & 606 & 744 & 0.83 & 0.90 & B & -18.54 & -31.16 & -2 \\
\hline & 81071322 & 635 & 482 & 0.44 & 0.95 & - & 31.67 & -92.19 & 0 \\
\hline & 83072706 & 713 & 708 & 0.81 & 0.93 & B & 0.66 & -45.63 & 4 \\
\hline Calibration & 83093000 & 716 & 1290 & 0.80 & 0.80 & B & -44.50 & 0.76 & 2 \\
\hline \multirow[t]{5}{*}{ Period } & 84090116 & 572 & 1210 & 0.70 & 0.71 & B & -52.77 & -11.29 & 2 \\
\hline & 88080808 & 441 & 602 & 0.57 & 0.82 & $\mathrm{C}$ & -26.72 & -30.22 & -2 \\
\hline & 90072012 & 257 & 542 & 0.83 & 0.66 & B & -52.54 & -0.15 & 0 \\
\hline & 94070220 & 194 & 1210 & 0.36 & 0.46 & - & -84.00 & 33.20 & 4 \\
\hline & 95081110 & 442 & 848 & 0.53 & 0.72 & $\mathrm{C}$ & -47.88 & -28.53 & 2 \\
\hline \multirow{3}{*}{$\begin{array}{c}\text { Validation } \\
\text { Period }\end{array}$} & 96080100 & 760 & 1730 & 0.54 & 0.82 & $\mathrm{C}$ & -56.08 & 20.51 & 4 \\
\hline & 96091618 & 397 & 809 & 0.75 & 0.83 & B & -50.98 & -14.37 & 0 \\
\hline & 98080304 & 511 & 1320 & 0.58 & 0.62 & $\mathrm{C}$ & -61.30 & 0.37 & 0 \\
\hline
\end{tabular}

Note: in the table "Per-e" means permissible error, and "A- Time" means Appear time. 


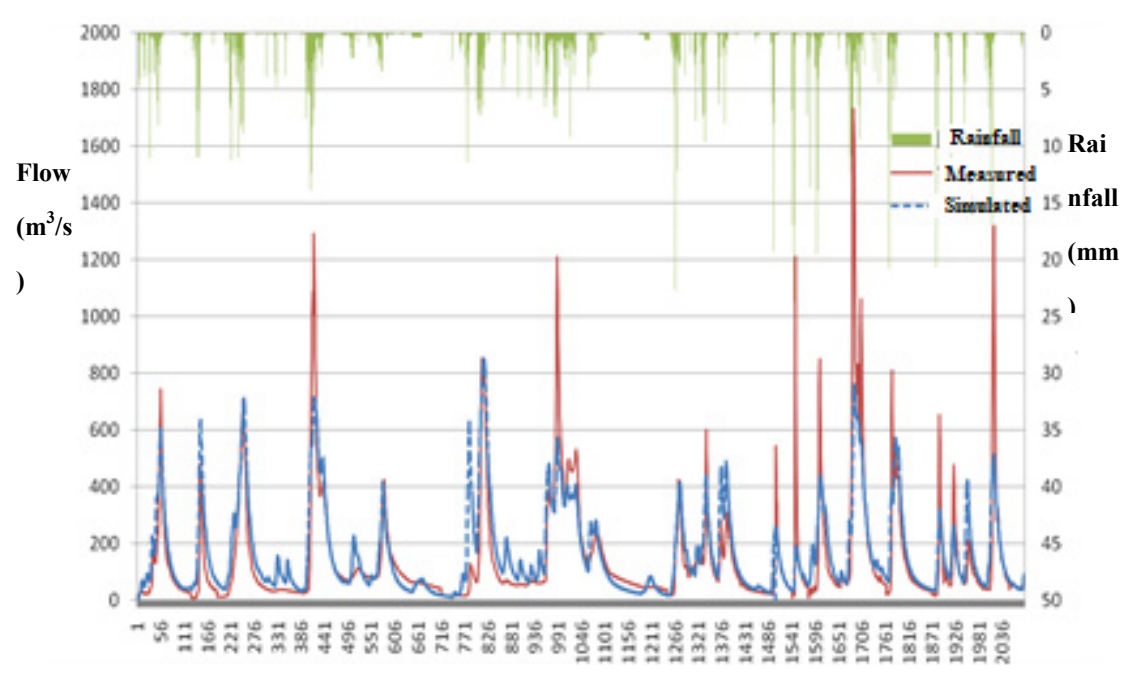

Figure 3. The fitted situation of the simulative flood and the measured flood

The results of the model reveal that the Nash-Sutcliffe of the calibration period and the validation period are respectively 0.80 and 0.72 . The squares of RSQ - R2-are 0.72 and 0.75 . Both of the Nash-Sutcliffe and the RSQ reach B level, which are available for forecasting. There are 6 floods whose Nash-Sutcliffe are between 0.7 and 0.9 and meet the level of B. 4 floods are between 0.5 and 0.7 . While, only two floods meet the permissible errors of flood peak within $\pm 20 \%$ that are satisfied the requirement of forecasting. Most relative errors of flood peak volume are in $\pm(20-60) \%$. The study indicates that there are several differences between each relative error of flood total amount. Within the 12 floods, only 5 floods match the permissible errors of $\pm 20 \%$, of which the qualified rate is $41.4 \%$ that is lower than grade $\mathrm{C}$. In a word, the peak time error is relatively small given that the errors are within $\pm 4 \mathrm{~h} ; 4$ floods of which the errors are $0 \mathrm{~h}$ hold $1 / 3$ of the total flood number. Apparently, several factors bring out errors. Firstly, for the reason that all the basic data were measured value which can't spare with certain error exists in the process of data collecting and data processing. The second factor causing error is uneven distribution of rainfall station and stream gauging station. Thirdly, the uncertainty that model parameter originally attached is doomed to result in error. The last but not the least, errors come from the accuracy degree of simulation. Because among the sample areas, some flood lasted for a short time with large rainfall which leaded to a flood surge and swoop.

From the perspective of fitted situation of flood hydrograph, the distributed hydrological models fit effectively for the errors are in allowable range. Meanwhile, the result of the Luhun model which is precise enough to meet the demand of accuracy can provide technology support for flood control of Luhun Catchment.

\subsection{The Characteristics of Runoff in Luhun Catchment}

Figure 4 illustrates the spatial distribution of Lunhun rainfall-runoff, covering the spatial distribution of flood runoff from(a1)to(a2)and the spatial distribution of rainfall from (b1) to (b2). For lack of space, only two examples of spatial distribution diagrams about flood rainfall-runoff are listed. . The average proportion value of each sub-stream in the 12 floods is showed in table 4 which reveals that the runoff and the proportion within the total study area in sub-stream 6 are the biggest. It is because that, covered with yellow brown soil and cinnamon soil, the sub-stream 6 has a complicated land utilization condition and is easily affected by human activity. After rain, water falls quickly in sub-stream 6, forming big water volume. In allusion to rainstorm center, there are 7 rainstorms whose centers are in the upstream. However, there are more rainstorms whose centers are on the lower part of the river within less rainfall compared with upstream. Referring to each amount of runoff procedure chart, here comes the conclusion that flood, whose rainfall center is in downstream, has a short time from rain falling to flowing together to the catchment exit because of the short confluence path. Thus, high volume runoff arises facilely in the catchment exit. However, the rainfall whose rainfall center is in midstream or upstream may produce high volume floods in catchment exit as well; since that there are more heavy rains which meet high level requirement and have rainfall center in upstream. 


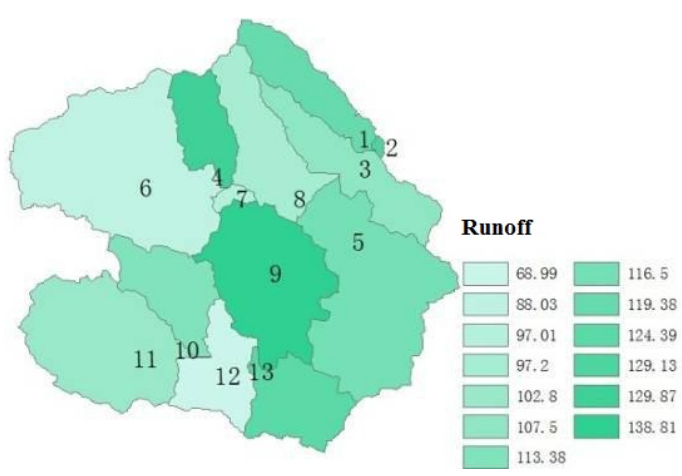

(a1) Runoff 88080808

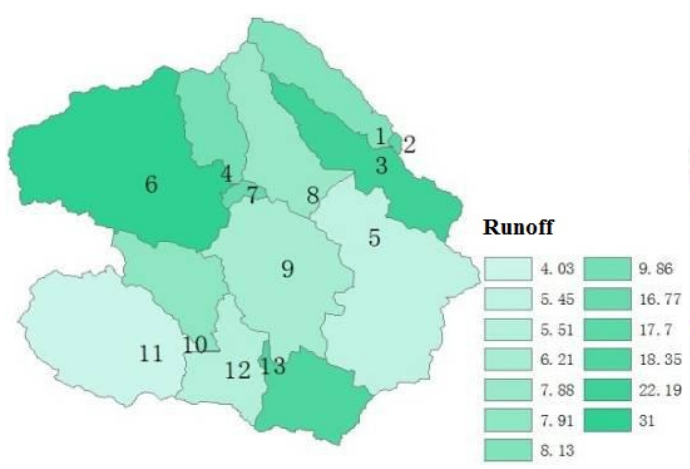

(a2)Runoff 94070220

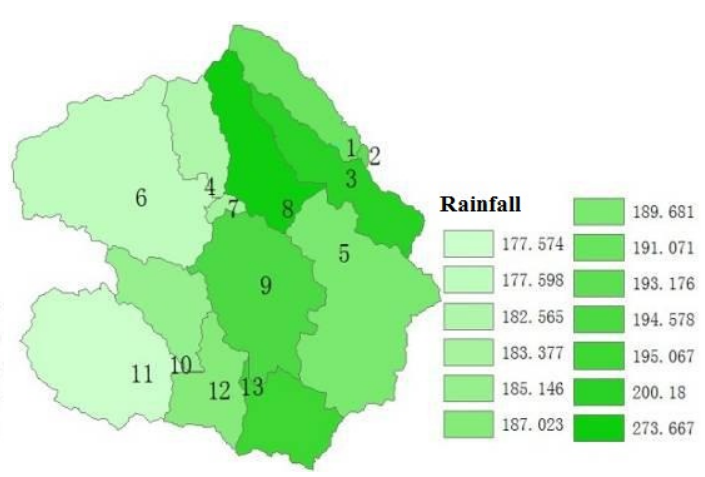

(b1) 1Rainfall 88080808

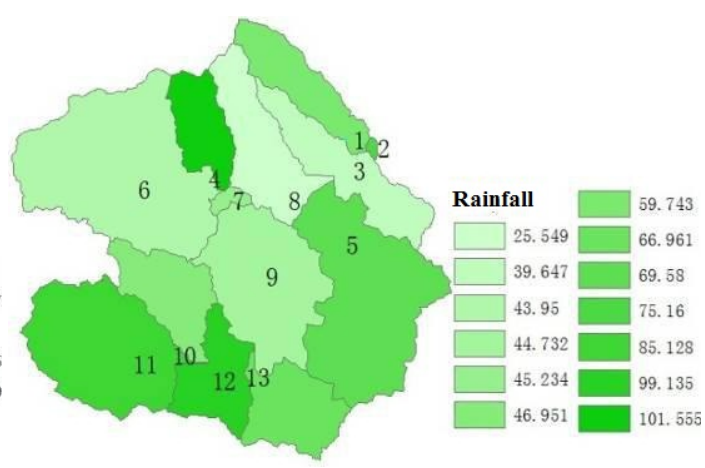

(b2) Rainfall 94070220

Figure 4 . The distribution of runoff and rainfall for every flood

Table 4. Percentage of the Substreams in total runoff

\begin{tabular}{cccc}
\hline No. & Percentage $(\%)$ & No. & Percentage $(\%)$ \\
\hline 1 & 5.63 & 8 & 7.53 \\
2 & 0.16 & 9 & 12.64 \\
3 & 6.95 & 10 & 6.49 \\
4 & 4.16 & 11 & 12.73 \\
5 & 13.06 & 12 & 4.79 \\
6 & 18.98 & 13 & 6.40 \\
7 & 0.54 & & \\
\hline
\end{tabular}

The comparison diagram of runoff and rainfall distribution denotes that rainfall center impacts the formation of runoff. Sub-catchments with rainfall center or high rainfall represent a significant proportion in cases. Sub-catchment with high rainfall does not necessarily have great runoff, such as floods 95081110, 94070220, 90072012,83093000 etc. Take flood 94070220 for example, sub-catchments including number 4, 10, 11 and 12 , have a relatively high rainfall with the rainfall of $85 \mathrm{~mm}-100 \mathrm{~mm}$. The volumes are $17.7 \mathrm{~m}^{3} / \mathrm{s} 、 6.21 \mathrm{~m}^{3} / \mathrm{s} 、 5.45 \mathrm{~m}^{3} / \mathrm{s}$ 、 $5.51 \mathrm{~m}^{3} / \mathrm{s}$ respectively. For sub-catchment 6 , the rainfall is $43 \mathrm{~mm}-45 \mathrm{~mm}$. Though with a low rainfall, sub-catchment 6 forms a high runoff as $31.3 \mathrm{~m}^{3} / \mathrm{s}$ which accounts for $19.25 \%$ of the total rainfall in the catchment, which may be related to its ground condition.

Table 5. Frequency distribution table for floods of Luhun reservoir

\begin{tabular}{cccccc}
\hline Frequency P(\%) & Recurrence interval(Y) & $\begin{array}{c}\text { Flood peak } \\
\left(\mathrm{m}^{3} / \mathrm{s}\right)\end{array}$ & $\begin{array}{c}\text { Frequency } \\
\mathrm{P}(\%)\end{array}$ & $\begin{array}{c}\text { Recurrence interval } \\
(\mathrm{Y})\end{array}$ & $\begin{array}{c}\text { Flood peak } \\
\left(\mathrm{m}^{3} / \mathrm{s}\right)\end{array}$ \\
\hline $0.1 \%$ & 1000 & 9235 & $20 \%$ & 5 & 1609 \\
$1 \%$ & 100 & 5722.3 & $50 \%$ & 2 & 691.2 \\
$5 \%$ & 20 & 3399.4 & $75 \%$ & 1.3 & 430.6 \\
$10 \%$ & 10 & 2470.2 & $99.9 \%$ & 1 & 377.3 \\
\hline
\end{tabular}


Flood frequency analysis result of Dongwan Station is presented in table 5 which tells that the flood peak is $1609 \mathrm{~m}^{3} / \mathrm{s}$ if flood happens once per 5 years, and the flood peak is $5722.3 \mathrm{~m}^{3} / \mathrm{m}$ if flood occurs once per 100 year.

Table 6. The grade and influence of flood events

\begin{tabular}{|c|c|c|c|c|c|}
\hline $\begin{array}{c}\text { Serial } \\
\text { No. }\end{array}$ & Grade & $\begin{array}{l}\text { Range of } \\
\text { Frequency }\end{array}$ & Influence & Time & Flood No. \\
\hline 1 & small flood & $\begin{array}{l}\geq 50 \% \\
\leq 691\end{array}$ & $\begin{array}{l}\text { Small affected range } \\
\text { with small damage }\end{array}$ & 3 & $\begin{array}{c}8107132288080808 \\
90072012\end{array}$ \\
\hline 2 & medium flood & $\begin{array}{c}20-50 \% \\
691-1609\end{array}$ & $\begin{array}{c}\text { A part low lands being } \\
\text { drown }\end{array}$ & 8 & $\begin{array}{ll}80062904 & 83072706 \\
83093000 & 84090116 \\
94070220 & 95081110 \\
96091618 & 98080304\end{array}$ \\
\hline 3 & great flood & $\begin{array}{c}10-20 \% \\
1609-2470\end{array}$ & $\begin{array}{c}\text { A part cultivated land } \\
\text { be affected }\end{array}$ & 1 & 96080100 \\
\hline 4 & $\begin{array}{l}\text { defensibility } \\
\text { extreme flood }\end{array}$ & $\begin{array}{c}5-10 \% \\
2470-3399\end{array}$ & $\begin{array}{c}\text { Suffer damage that can } \\
\text { be cut down by } \\
\text { measures }\end{array}$ & 0 & \\
\hline 5 & $\begin{array}{l}\text { disastrously } \\
\text { extreme flood }\end{array}$ & $\begin{array}{c}\leq 5 \% \\
\geq 3399\end{array}$ & Disaster loss & 0 & \\
\hline
\end{tabular}

Referring to the definitions of extreme flood events and flood, floods are separated into 5 levels according to the result of flood frequency analysis. They are small flood, medium flood, great flood, defensibility extreme flood event, disastrously extreme flood event. Table 6 indicates the levels of chosen and analytic 12 floods with relative flood number. As the chart presents, there are 3 small floods, 8 medium floods and one great flood. The rainfalls are $55.3 \mathrm{~mm}, 169.3 \mathrm{~mm}, 58.6 \mathrm{~mm}$ for small floods-81071322, 88080808 and 90072012 . The characteristics of rainfall spatial distribution of the three floods reveal that small floods come from rainstorm with storm center in upstream, high rainfall and long lasting time. For example, focusing in months from August to October 1988, flood 88080808 has a high overall amount of rainfall and lasted as long as $482 \mathrm{~h}$ and it generated small flood on account of that not merely the rainfall declined in later period but its rainfall center is in upstream. Assume the rainstorm center was in downstream and the rainfall was small, it could also easily form small flood. Most rainstorm centers of the 8 medium floods focused in upstream for instance sub-catchments 6 , $10,11,13$ and so on. By analysis, these medium floods formed for high rainfall and significant proportion, which sum-catchments 5, 6, 9 occupy, of runoff in total volume. With small difference on rainfall among all section and simple ground conditions, great flood such as 96080100 , whose rainfall is $132 \mathrm{~mm}$ and high rainfall is in sub-catchment $6,9,10,13$, occurs easily in case that the runoff can be less affected by human activity.

By way of conclusion, there are more medium floods in Lunhun Catchment; small rainfall and rain in upstream easily produce small flood; And medium or great flood comes from medium or great rainstorm of which the rainfall centers focus in sub-catchments 5, 6, 9, 10 and 11 .

For each flood level partitioned above, flood control scheduling work should consider the following several tips according to the ground condition of basin controlled by Luhun Catchment and the real situation of flood control role.

(1) The flood peak volume is $1609 \mathrm{~m}^{3} / \mathrm{s}$ for flood that happens per 5 years. And it belongs to small flood. The average rainfall is $85 \mathrm{~mm}$ in the relative area. Because small and medium floods occur frequently in Luhun Catchment, some basic method and strategy are necessary for avoiding or reducing loss in order to strengthen our work on medium flood control.

(2) Though there are few great floods in Luhun Catchment, precaution is certainly needed. Great flood comes with certain disastrous risk for catchment. For the reason that the risk is acceptable in catchment, we can apply some measures to defense it in advance.

(3) As for defensibly extreme flood event and disastrously extreme flood event, we should take actions to reduce loss as soon as possible though the flood is not defensive.

(4) Most rainstorms happen in sub-streams 5, 6, 9, 10, 11 and 12 and the flood processes are often long in outlet of the catchment. Therefore, when this kind of flood occurs, relative flood control measure should be adopted including main prevention of high level rainfall whose rainstorm center is in midstream and downstream. 


\section{Conclusions}

According to the distribution hydrologic model of stored-full runoff and runoff under excess infiltration model, the paper has simulated the runoff of Luhun Catchment. In combination with the result and ArcGIS software technology, Luhun Catchment is divided into 13 sub-catchments. Based on this, it analyzes spatial distribution characteristics of rain runoff in the catchment and its flood process. More rainfall centers of rains are in upstream. In this area, soil and natural vegetation have great effect on the runoff. With good natural vegetation and small effect of human activity, sub-catchments 5, 6, 9, 10 and 11 account for large proportion of the total runoff. Finally, flood control scheduling strategies of Luhun Catchment are put forward on the basis of flood process in Luhun Catchment.

\section{Acknowledgements}

The research was funded by the National Natural Science Foundation of China, No. NSCF-51079131 and No.51479180, and the experimental subject named "CMA/Henan Key Laboratory of Agrometeorological Support and Applied Technique (AMF201304)". The authors are grateful to all colleagues and friends who have shared their meteorological and hydrological data with us. We also thank all reviewers for their insightful comments that have improved the original draft of this paper

\section{References}

Akhavana, S., Abedi-Koupaia, J., Mousavia, S., Afyuni, M., Eslamian, S., \& Abbaspour, K. C. (2010). Application of SWAT model to investigate nitrate leaching in Hamadan-Bahar watershed, Iran, Journal of Agriculture, Ecosystems and Environment, 139(4), 675-688. http://dx.doi.org/10.1016/j.agee.2010.10.015

Bandaragoda, C., Tarboton, D. G., \& Woods, R. (2004). Application of TOPNET in the distributed model intercomparison project. J. Journal of Hydrology, 298(1-4), 178-201. http://dx.doi.org/ 10.1016/j.jhydrol.2004.03.038

Bao, W. M. (2007). Hydrologic Forecasting. Beijing, China: China waterpower press.

Beven, K. (2004). Infiltration excess at the Horton Hydrology Laboratory (or not?), Journal of Hydrology, 293(1-4), 219-234. http://dx.doi.org/10.1016/j.jhydrol.2004.02.001

Beven, K. J., \& Kirkby, M. J. (1979). A physically based variable contributing area model of basin hydrology, Hydrological Sciences Bulletin, 24(1), 43-69.

Breckpot, M., Agudelo, O. M., Meert P., \& Willems, P. (2013). Flood control of the Demer by using model

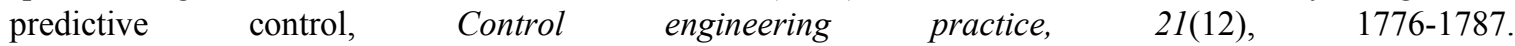
http://dx.doi.org/10.1016/j.conengprac.2013.08.008

Ceccato, L., Giannini, V., \& Giupponi, C. (2011). Participatory assessment of adaptation strategies to flood risk in the Upper Brahmaputra and Danube river basins, (12). Environmental science \& policy, 14(8), 1163-1174. http://dx.doi.org/10.1016/j.envsci.2011.05.016

Chen, Y., Ren, Q., Xu, H., \& Huang, F. (2010). Liuxihe model I:Theory and methods. Acta Scientiarum Naturallum Universitatis Sunyatsent, 49(1), 107-112.

Cheng, C. T., \& Chau, K. W. (2004). Flood control management system for reservoirs. Enviromental Modelling \& Soft, 19(12), 1141-1150. http://dx.doi.org/10.1016/j.envsoft.2003.12.004

Cuartas, L. A., Tomasellaa, J., Nobrea, A. D., Nobre, C. A., Hodnett, M. G., Waterloo, M. J., ... Ferreira, M. (2012). Distributed hydrological modeling of a micro-scale rainforest watershed in Amazonia: Model evaluation and advances in calibration using the new HAND terrain model, Journal of Hydrology Volumes, 462-466, 15-27. http://dx.doi.org/10.1016/j.jhydrol.2011.12.047

Hu, C., \& Wang, J. (2010). Watershed runoff model and hydrological models. Zhengzhou, China: The Yellow River water conservancy press.

Hu, C., Go, S., Xiong, L., \& Peng, D. (2005). A modified Xinanjiang model and its application in Northern China, Nordic Hydrology, 36(3), 1-19.

Kumar, D. N., Baliarsingh, F., \& Raju, K. S. (2010). Extended Muskingum method for flood routing, Journal of Hydro-environment Research, 5(2), 127-135. http://dx.doi.org/10.1016/j.jher.2010.08.003

$\mathrm{Li}, \mathrm{X}$. (2011). The study and application of hydrological coupling model based on the surface and groundwater dynamic exchange. (Master thesis, Zhengzhou University, Zhengzhou, China). Retrieved from http://epub.cnki.net/kns/default.htm 
Liu, X., Hu, C., Wang, Y., \&Wu, Z. (2005). Risk analysis of staged flood-water resources utilization for Luhun reservoir, Journal of Irrigation and Drainage, 24(5), 56-59.

Wood, W. L. (1996). A note on how to avoid spurious oscillation in the finite-element solution of the unsaturated flow equation. Journal of Hydrology, 176(1-4), 205-218. http://dx.doi.org/10.1016/0022-1694(95)02790-4

World Meteorological Organization. (WMO 1975). Intercomparison of conceptual models used in operational hydrological forecasting. WMO Oper. Hydrol. Rep. 7, WMO 429.

World Meteorological Organization. (WMO 1986). Intercomparation of models for snowmelt runoff. WMO Oper. Hydrol. Rep. 23, WMO 646.

Xia, H. (2005). Flood risk management in China. (Master thesis, China Agricultural University, Beijing, China). Retrieved from http://epub.cnki.net/kns/default.htm

$\mathrm{Xu}$, J., Hu, C., \& Wu, Z. (2011). Application study of discrete differential dynamic programming on the reservoir optimal operation, Meteorological and Environmental Sciences, 34(4), 79-83.

Zhan, D. J., \& Ye, S. Z. (2006). Engineering hydrology, Beijing, China: China WaterPower Press.

Zhao, L., Zhang, P., \& Zhang, H. (2010). Research and development on optimization scheduling system for Luhun reservoir, Yellow River, 32(8), 67-70.

Zhao, R. (1980). The Xinanjiang model, Proceedings Oxford Symposium (pp. 351-356). Oxford.

\section{Copyrights}

Copyright for this article is retained by the author(s), with first publication rights granted to the journal.

This is an open-access article distributed under the terms and conditions of the Creative Commons Attribution license (http://creativecommons.org/licenses/by/3.0/). 